\title{
The Effectiveness of informational Services Through Small Group Discussion to Improve Students Tolerance Attitudes
}

\author{
Sally Putri Karisma ${ }^{1}$, Neviyarni ${ }^{2}{ }^{2}$, Solfema ${ }^{3}$ \\ ${ }^{123}$ Padang State University \\ *Corresponding author, e-mail: sally@konselor.org
}

\begin{abstract}
Tolerance is very important to maintain diversity in Indonesia, so it needs to be grown early. Students need to have tolerance to respect each other, accept and acknowledge the differences and diversity of religions, ethnicities, beliefs and opinions of others. This study aims to determine the effectiveness of information services with a small group discussion approach to improve student tolerance. The sample of this study consisted of 36 students selected by cluster random sampling techniques. The instrument used was a tolerance scale with a reliability of 0.844 . Data analysis in this study used a one group pretest-posttest approach. The results showed that students have a very high attitude of tolerance, with an average achievement of $97.22 \%$. The implications of this study are as a basis for counselors to improve student tolerance.
\end{abstract}

Keywords: Small Group Discussion, Student Tolerance Attitudes

This is an open access article distributed under the Creative Commons 4.0 Attribution License, which permits unrestricted use,

distribution, and reproduction in any medium, provided the original work is properly cited. @2020 by Author

\section{Introduction}

Tolerance is an attitude of respecting diversity (Corneo \& Jeanne, 2009) and an effort to create harmony from difference (Bilgili, 2015). UNISCO (in Bangwayo-Skeere \& ikhali, 2013), defines tolerance as "respect, acceptance and appreciation of the rich diversity of our world cultures, our forms of expression and ways of being human". Tolerance is harmony in difference (Persell, Green, \& Gurevich, 2001). Tolerance can also be interpreted as a measurement limit in addition or reduction that is still allowed (Munawir, t.th). Tolerance is endurance and patience with practices and beliefs that are disliked, disapproved and rejected (Verkuyten \& Slooter 2007). Tolerance as an attitude that allows freedom of expression of peace and conception of freedom to those who disagree with religion, race, caste or custom (Galeotti 2004; Pasamonik 2004). UNESCO (1995) Associates tolerance with affirmation and appreciation of differences by defining tolerance as acceptance, respect, affirmation and appreciation of religious diversity, ethnic opinions and ways of life.

As humans who live in a social environment, they should have and embrace tolerance towards others to maintain unity in the midst of diversity, maintain harmony in social life, 
avoid divisions, increase brotherhood, and create peace, a sense of peace and security, so that it will be realized DBMBS life (peaceful, developing, progressing, happy and prosperous) and the creation of students possessing intelligent characters (Prayitno, 2017). The educational environment is very decisive and influences the formation of attitudes, acceptance, behavior, and tolerance of each student to a variety of diversity (ethnicity, organization, and religion) (Bakhori, 2010).Therefore it is necessary to provide information for students about tolerance. One of the services that counselors can provide is information services.

Information services are a type of service in Guidance and Counseling (BK) to help students receive and understand various information on self, social, learning, career or position, and further education in a directed, objective, and wise manner (Prayitno et al, 2015). Information services as a guidance service that allows students and other parties who can have a big influence on students (especially parents) in receiving and understanding information that can be used as consideration and decision making (Sukardi, 2007). Information services intend to provide understanding to individuals and groups concerned about various things needed to carry out a plan for the objectives to be achieved (Jaya, 2004).

Information services by using a small group discussion approach students are able to gain insight, new knowledge and gain the ability to express themselves through small group discussions related to understanding about peace in life, respect for others and awareness in the surrounding environment. In addition it stimulates student creativity in the form of ideas, ideas, and new breakthroughs in problem solving, developing an attitude of respecting the opinions of others, broadening insight, fostering to get used to deliberation to reach consensus in solving a problem.

\section{Method}

This study uses a one group pretest-posttest approach. Research subjects were conducted on high school students in Jayapura, Papua, Indonesia. The sample in this study were 39 high school students from Jayapura 2 Jayapura selected by cluster random sampling technique. This research instrument uses the grand theory of (Tilman, 2004) with aspects developed by researchers, including covering aspects of peace, respecting differences and individuals, and awareness. The questionnaire uses a scale of tolerance that includes aspects of peace, respecting individual differences, and awareness. The instrument was developed using a Likert scale model. To test the validity of researchers using Product Moment, to obtain the results of 73 items there are 62 items that are declared valid and 11 items declared invalid. To see the reliability of the instrument is done by comparing the Alpha Cronbach Minimum price with the Alpha Cronbach instrument, with a Minimum Cronbach Alpha value of 0.80 . Based on the results of data processing that has been done, Alpha Cronbach's value is 0.844 , which means $0.80 \geq 0.844$ so it can be concluded that the instrument is reliable or has a high level of reliability. Data processing in this study uses SPSS (Statistical Product and Service Solution) for windows release 20.00.

\section{Results and Discussion}

Based on the results of research from 36 students as follows 
Table 1. Pretest and Posttest Results of Student Tolerance Attitudes

\begin{tabular}{|l|l|c|c|c|c|}
\hline \multirow{2}{*}{ Score interval } & \multirow{2}{*}{ Caregory } & \multicolumn{2}{|c|}{ Pretest } & \multicolumn{2}{c|}{ Posttest } \\
\cline { 3 - 6 } & & $\mathbf{f}$ & $\mathbf{\%}$ & $\mathbf{f}$ & $\mathbf{\%}$ \\
\hline$\geq 262$ & Very high & 0 & 0 & 35 & 97,22 \\
\hline $212-261$ & High & 33 & 8,33 & 1 & 2,78 \\
\hline $162-211$ & Average & 8 & 22,23 & 0 & 0 \\
\hline $112-161$ & Low & 18 & 50 & 0 & 0 \\
\hline$\leq 111$ & Very low & 7 & 19,44 & 0 & 0 \\
\hline \multicolumn{1}{|c|}{ Total } & $\mathbf{3 6}$ & $\mathbf{1 0 0}$ & $\mathbf{3 6}$ & $\mathbf{1 0 0}$ \\
\hline
\end{tabular}

From the table above, it can be explained that the provision of information services using the small group discussion approach is able to increase the tolerance attitude of students with a very high category that is $97.22 \%$, this shows that the information service using the small group discussion approach is effective in increasing student tolerance

The implementation of information service treatment using a small group discussion approach in increasing student tolerance was carried out during 8 meetings. The description of the implementation is as follows.

Table 2. Description of the Implementation of Information Services Using the Small Group Discussion Approach

\begin{tabular}{|l|l|}
\hline \multicolumn{1}{|c|}{ Activity step } & \multicolumn{1}{c|}{ Implementation of Activities } \\
\hline \multirow{5}{*}{ Early stage } & $\begin{array}{l}\text { 1. Say hello. } \\
\text { 2. Invite students to pray. } \\
\text { 3. Check student attendance. } \\
\text { 4. Asking students for readiness. } \\
\text { 5. Delivering the material, objectives and methods used }\end{array}$ \\
\hline 1. Divide the class into several small groups. \\
2. Give questions (topics / material) to each group. \\
3. Explain student assignments and invite students to discuss \\
and discuss the material / topic that has been given. \\
4. Ensure that each group actively participates in discussions. \\
5. Instruct each group member through the designated \\
spokesperson to present the results of their discussion in front of \\
the class. \\
6. Ask other group members to respond / ask questions. \\
7. The appearance of yells. group.
\end{tabular}


Discussion of the results of research that is about the effectiveness of information services using a small group discussion approach to improve student tolerance. Based on the results of pretest and posttest data processing using Wilcoxon Signed ranks Test, the calculation results are as follows.

Table 3. Results of Wilcoxon Signed Rank Analysis Test for Student Tolerance Attitudes (Pretest and Posttest)

\begin{tabular}{|l|r|}
\hline & \multicolumn{2}{|c|}{ Posttest - Pretest } \\
\hline$Z$ & $-5,303^{\mathrm{b}}$ \\
\hline Asymp. Sig. (2-tailed) &, 000 \\
\hline
\end{tabular}

a. Wilcoxon Signed Rank Test

b. Based on negative rank

Based on the results above it can be seen that the Asymp probability number. Sig. (2tailed) tolerance of students is 0,000 , or the probability is smaller than alpha $0.05(0.000 \leq$ 0.05). From these results it can be said that there are differences in student tolerance between prior to being given information services using the small group discussion approach and after being given information services using the small group discussion approach. This difference can be seen from the decrease in the average score of student tolerance, where the posttest score is lower than the pretest score, with an average score of 150,81 compared to 287,72 .

Based on research results, it is known that information services using the small group discussion approach are effective in increasing student tolerance. Of the 36 students who provided information services using the small group discussion approach, all experienced an increase in the tolerance attitude score. This is because information services using the small group discussion approach can not only improve students' knowledge and understanding, but also can train students to be able to change and control behavior related to the conditions they face. In line with researchers, research conducted at UAD found that the application of small group discussions was able to improve the learning outcomes and effectiveness of PGSD students (Purwati, S, 2017). Next, the researcher made clear with figure 1 about the effectiveness of information services by using a small group discussion approach to improve student tolerance.

In Figure 1 shows the differences in the tolerance attitude of students before and after being given information services using the small group discussion approach, where the tendency of the red beam (posttest) is higher than the blue beam (pretest), this indicates the effect of information services using the smal approach group discussion makes an increase in student tolerance. Changes between the pretest and posttest given to 36 students all experienced changes, so that it is in the category of very high tolerance. One of the ways to improve students' tolerance is by providing information services using a small group discussion approach with material peace, respecting individual differences and awareness 
Figure 1. Student Tolerance Attitude Graph (Pretest-Posttest)

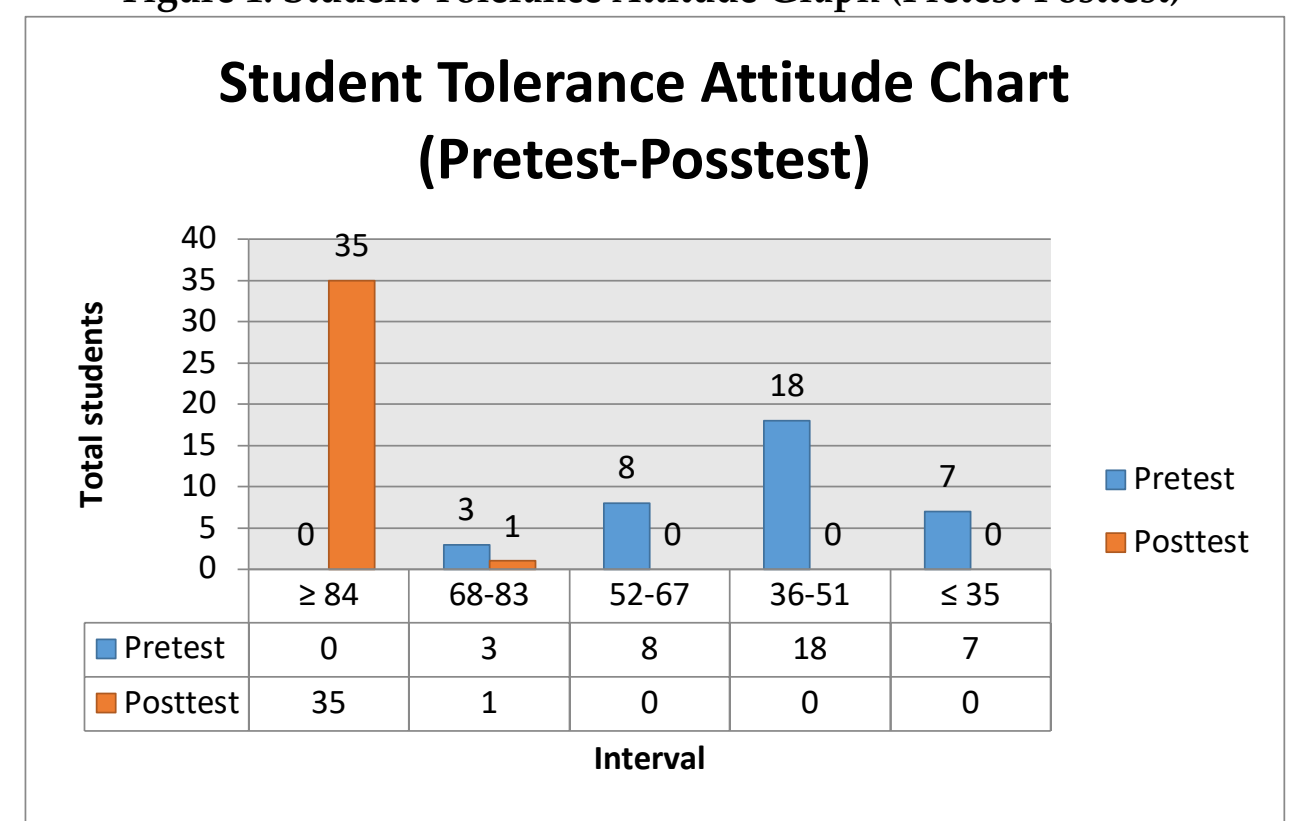

In the implementation of small group discussions provide opportunities for students to share information and experiences in solving a problem (Christiani \& Mintohari, 2014). By sharing information in the learning process students are able to emphasize the activity of learning, because it can directly communicate with other members in groups that are not too much during group discussions. Through small group discussions students are encouraged to explore ideas, increase understanding of some new things, encourage development thinking, communicating effectively, improving group cooperation, increasing student involvement in making decisions, and also as a technique for solving problems (Ahmad, R, 2017). At the end of the information service that has been provided by researchers, researchers provide evaluations to students by asking students to BMB3 (think, feel, behave, act and take responsibility).

\section{Conclusion}

The results showed that the information service using the small group discussion approach was effective in increasing the tolerance attitude of students of SMA Negeri 2 Jayapura. This can be seen from the aspect of peace, respecting individual differences and awareness. This finding can be used as a reference for future researchers who want to conduct research on tolerance by choosing other approaches and methods. The results of this study can also be used by counselors as preliminary data to improve student tolerance through guidance and counseling services.

\section{References}

Bangwayo-Skeete, P.F., \& Zikhali, P. (2013). "Explaining self-declared social tolerance for human diversity in Latin America and the Caribbean". Forum for Social Economics, 42 (2-3), 181-206.

Bilgili, N.C. (2015). "Religiosity and tolerance in Turkey: is Islam the problem?", Southeast European and Black Sea 1-21. http://dx.doi.org/10.1080/14683857.2015.1063794. 
Bukhori, B. (2010). "Prasangka terhadap pemeluk agama lain dalam perspektif teori belajar sosial dari Albert Bandura". Jurnal Psikologi, 3(1), 29-36.

Corneo, G., \& Jeanne, O. (2009). "A Theory of tolerance”. Journal of Public Economics 93, nos. 5-6: 691-702.

Galeotti, A. E. (2004). Toleration as recognition. New York: Cambridge University Press.

Ismail, S.M. (2008). Strategi pembelajaran agama Islam berbasis PAIKEM. Semarang: Rasail.

Jaya, Y. (2004). Bimbingan konseling agama Islam. Padang: Angkasa Raya

Munawir, A.W. t.th. Kamus Arab Indonesia al-Munawir. Yogyakarta: Balai Pustaka Progresif.

Persell, C.H., Green, A. \& Gurevich, L. (2001) “Civil society, economic distress and social tolerance". Sociological Forum, 16 (2): 203-230.

Prayitno, dkk. (2015). Pembelajaran melalui pelayanan BK di satuan pendidikan. Yogyakarta: Paramitra.

Prayitno. (2017). Konseling profesional yang berhasil: Layanan dan kegiatan pendukung. Jakarta: Rajawali Pers.

Purwanti, S. (2017). "Penerapan small group discussion untuk meningkatkan hasil belajar dan keaktifan mahasiswa PGSD UAD". Jurnal Dialektika Jurusan PGSD, 7 (1): 10-19.

Ramadhani, E. (2016). Efektivitas layanan informasi menggunakan pendekatan discovery learning dalam meningkatkan aspirasi karier siswa. Tesis tidak diterbitkan. Padang: Program Pascasarjana FIP UNP.

Rofiqoh. (2015). Penanaman sikap toleransi beragama dalam pendidikan agama (Studi atas Agama Islam, Kristen, dan Katolik di SMK YPKK 2 Sleman Yogyakarta). Tesis tidak diterbitkan. Yogyakarta: Program Pascasarjana UIN Sunan Kalijaga.

Sa'adiyah, R. (2015). “The influence of religious motivation and student learning outcomes in Islamic religious education towards students tolerance attitude". Jounal of Education in Muslim Society. 2 (1): 70-82.

Sukardi, D.K. (2007). Pengantar pelaksanaan program bimbingan dan konseling di sekolah. Jakarta: Rineka Cipta.

Talib, A.T., \& Gill, S.S. (2012). "Socio-religious tolerance: Exploring the Malaysian experince". Global Juornal of Human Social Science. 12 (8): 49-54

Tilman, Diane. (2004). Pendidikan nilai untuk kaum muda dewasa (Terjemahan Risa Pratono). Jakarta: Grasindo. 
UNESCO. (1995). "Declaration of principles on tolerance." Accessed April 8, 2019.http://www.unesco.org/webworld/peace_library/UNESCO/HRIGHTS/124129.HTM

Verkuyten, M. (2007). "Religious group identification and inter-religious relations: A study among Turkish-Dutch Muslims". Group Processes \& Intergroup Relations. 10 (3): 341357. 